\title{
Why include humanities in medical studies: comment
}

\section{Jeremy Howick}

Internal and Emergency Medicine Official Journal of the Italian Society of Internal Medicine

\section{ISSN 1828-0447}

Intern Emerg Med

DOI 10.1007/s11739-019-02198-x

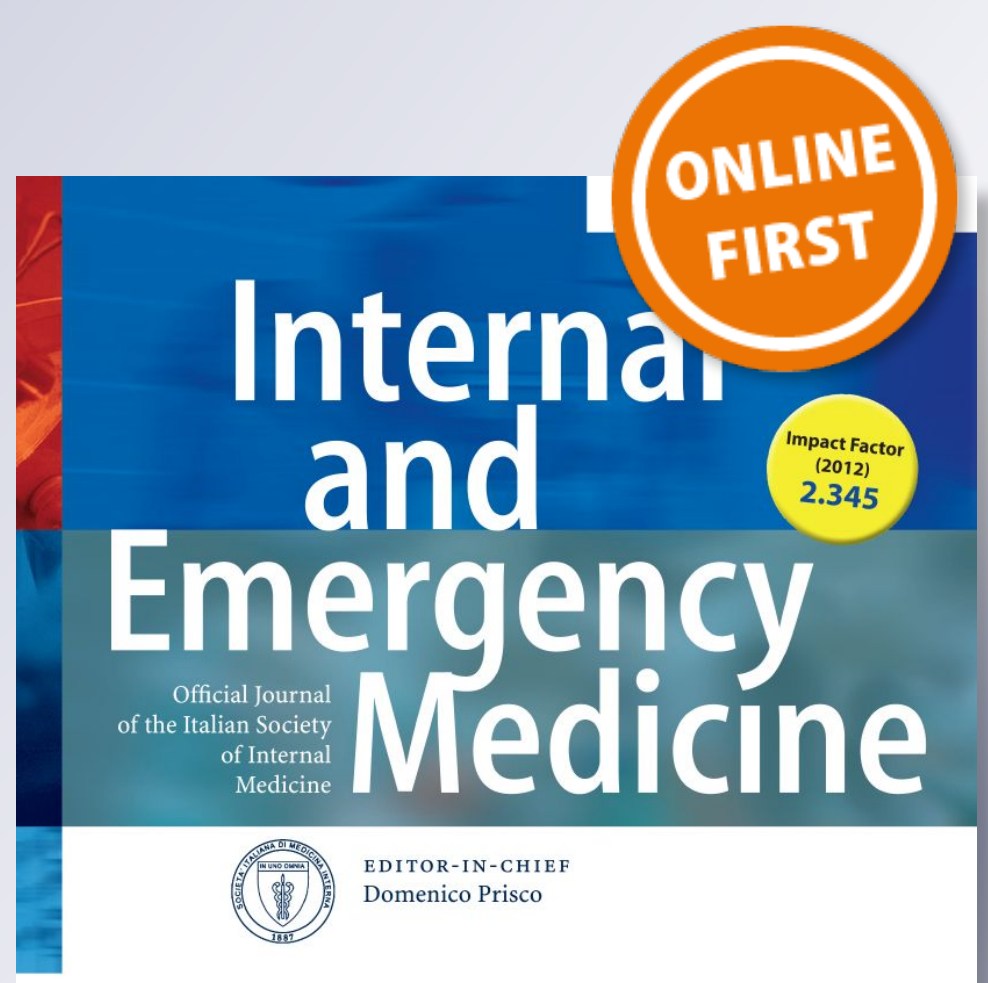

Springer 
Your article is protected by copyright and all rights are held exclusively by Società Italiana di Medicina Interna (SIMI). This e-offprint is for personal use only and shall not be selfarchived in electronic repositories. If you wish to self-archive your article, please use the accepted manuscript version for posting on your own website. You may further deposit the accepted manuscript version in any repository, provided it is only made publicly available 12 months after official publication or later and provided acknowledgement is given to the original source of publication and a link is inserted to the published article on Springer's website. The link must be accompanied by the following text: "The final publication is available at link.springer.com". 


\section{Why include humanities in medical studies: comment}

\author{
Jeremy Howick ${ }^{1}[$
}

Received: 22 August 2019 / Accepted: 17 September 2019

(c) Società Italiana di Medicina Interna (SIMI) 2019

\section{Dear Editor,}

In their article, Why include the humanities in medical studies? [1], Boniolo, Campaner, and Coccheri give good reasons why medical students benefit from studying the humanities, specifically philosophy. Below are additional reasons to take their arguments even more seriously.

1. A study published in The Lancet shows that medical students who study the humanities do better in medical school than those who do not $[2,3]$.

2. Studying the humanities is correlated with lower rates of burnout among medical students [4]. In a world where between $19 \%$ and $76 \%$ of physicians report burnout, this reason alone suffices to introduce the study of medical humanities into medical school curricula.

3. For many types of ailments and patients, medicine requires the art of communication and empathy. Empathy, which has been shown to improve patient outcomes [5], requires understanding. Such understanding can be difficult if we have not actually experienced what the patient is experiencing. Philosophy and the humanities provide a window into the human condition which facilitates understanding of other humans-patients—even if we have not personally walked in their shoes.

4. Relatedly, for medicine to be person-centred, it requires empathy and understanding, for which the humanities and philosophy are helpful—or indeed required [6].

5. For some medical problems, philosophy is not only desirable but necessary. The problem of "too much medicine" (TMM) is a good illustration of this. A main cause of TMM is "disease mongering," whereby diseases are all but invented. For example, it is normal to sometimes have trouble focusing on things sometimes. Yet there is now a name for its severe form: adult attention deficit

Jeremy Howick

jeremy.howick@philosophy.ox.ac.uk

1 University of Oxford, Oxford, UK disorder, which can be treated by methamphetamines (speed). Philosophy, which includes investigating the nature of disease, can constrain the problem of too much medicine by providing guidelines for what can legitimately count as an ailment. In fact, in the absence of such philosophising, it is open season for anyone (often, but not always drug companies with financial conflicts of interest) to promote non-diseases to promote a 'cure'.

6. No amount of studying the science of medicine can provide a guide to action, because all patient values and circumstances differ. Hence, the study of ethics cannot be ignored.

7. Feedback from many courses demonstrates that students love philosophy and the humanities. In a world where institutions of higher education are competing for the best students, this cannot be ignored. (See here, for example: https://www.conted.ox.ac.uk/courses/historyand-philosophy-of-evidence-based-health-care).

In short, studying philosophy and the medical humanities have many benefits and it is great to see that many medical schools are adopting these subjects as part of their core curricula.

\section{Compliance with ethical standards}

Conflict of interest I have no conflicts of interest relevant to this paper.

Statement of human and animal rights This article does not contain any studies with human participants or animals performed by any of the authors.

Informed consent For this type of study formal consent is not required.

\section{References}

1. Boniolo G, Campaner R, Coccheri S (2019) Why include the humanities in medical studies? Intern Emerg Med. https://doi. 
org/10.1007/s11739-019-02131-2 (published Online First: 2019/06/23)

2. Rolfe IE, Pearson S, Powis DA et al (1995) Time for a review of admission to medical school? Lancet 346(8986):1329-1333. https ://doi.org/10.1016/s0140-6736(95)92344-6 (published Online First: 1995/11/18)

3. Judson I (1996) Maturity in medical students. Lancet 347(8993):55 (published Online First: 1996/01/06)

4. Meakin R (2004) Editorial: philosophy in the undergraduate medical curriculum - beyond medical ethics. Med Humanit 30(1):53. https://doi.org/10.1136/jmh.2004.000148 (published Online First: 2004/06/01)

5. Howick J, Moscrop A, Mebius A et al (2018) Effects of empathic and positive communication in healthcare consultations: a systematic review and meta-analysis. J R Soc Med. https://doi. org/10.1177/0141076818769477

6. Bikker AP, Fitzpatrick B, Murphy D et al (2015) Measuring empathic, person-centred communication in primary care nurses: validity and reliability of the Consultation and Relational Empathy (CARE) Measure. BMC Fam Pract 16:149. https:// doi.org/10.1186/s12875-015-0374-y (published Online First: 2015/10/27)

Publisher's Note Springer Nature remains neutral with regard to jurisdictional claims in published maps and institutional affiliations. 